\title{
BEHAVIOURAL, ENDOCRINE AND METABOLIC EFFECTS OF FOOD RESTRICTION IN BROILER BREEDER HENS
}

\author{
L. KUBÍKOVÁ, P. VÝBOH, L. KOŠŤÁL \\ Institute of Animal Biochemistry and Genetics, Slovak Academy of Sciences \\ Ivanka pri Dunaji, Slovak Republic
}

Received May 7, 2001

Accepted August 28, 2001

\begin{abstract}
Kubíková L., P. Výboh, L. Koštál: Behavioural, Endocrine and Metabolice Effects of Food Restriction in Broiler Breeder Hens. Acta Vet. Brno 2001, 70: 247-257.

The effects of food restriction on behaviour, endocrine and metabolic parameters were studied in immature (13 weeks old) female breeding birds of the meat-type chickens (broiler breeders). Ad libitum fed hens were compared with those subjected to one qualitative (diet diluted with $30 \%$ hardwood sawdust) and two quantitative (the daily ration recommended by the breeding company and twice that amount) food restriction treatments. Behaviour of quantitatively restricted hens provided with one daily meal showed marked diurnal variation, while that of hens with free access to food (ad libitum fed and qualitatively restricted) was more evenly distributed throughout the day. There were elevated plasma corticosterone concentrations in hens subjected to intensive quantitative restriction. Although an increase in corticosterone concentrations of hens subjected to qualitative food restriction was lower, it was significant in comparison with ad libitum control, indicating that even mild qualitative food restriction is stressful. Compared to ad libitum fed hens, there were decreased plasma $\mathrm{T}_{3}$ concentrations in all food restriction treatments, while plasma $\mathrm{T}_{4}$ concentrations increased in intensively quantitatively restricted hens. Food restriction did not affect plasma glucose and total proteins, whereas triacylglycerol levels were decreased and cholesterol increased as a consequence of restriction. Creatinine level was increased in hens with less intensive quantitative restriction and plasma concentration of uric acid was decreased in qualitatively restricted hens in comparison with all other treatments. These results suggest that although behaviour of qualitatively restricted-fed hens resemble more to that of ad libitum-fed hens, their physiological status reminds more quantitatively restricted ones.
\end{abstract}

Domestic chicken, welfare, corticosterone, thyroid hormones

The major welfare problems in meat type chickens (broilers) are those, which can be regarded as side effects of the intense selection for growth and food conversion. These include leg disorders, contact dermatitis, ascites and sudden death syndrome in growing birds. It is apparent that the fast growth rate of current broiler strains is not accompanied by a satisfactory level of welfare including health (Report of the Scientific Committee on Animal Health and Animal Welfare of the EU Commission 2000).

High body weight of ad libitum fed (like the progeny) breeding birds (broiler breeders) is associated with excessive fat deposition, lameness, high mortality associated with skeletal and heart disease (Katanbaf et al. 1989; Savory et al. 1993; Hocking 1999), impaired immune function (Han and Smyth 1972; O' Sullivan et al. 1991; Hocking et al. 1996), and reduced fertility in both sexes (Nestor et al. 1980; Hocking et al. 1987; Hocking and Duff 1989; Robinson et al. 1993). In order to limit the body weight of breeding birds at sexual maturity (about 24 weeks of age), to reduce related health problems, and to increase fertility, the chronic food restriction is applied routinely in commercial conditions. The main welfare problems of broiler breeders are related to the severe food restriction. 
Hens fed on the restricted rations recommended by the breeding companies provided once a day are much more active than ad libitum fed control hens and show increased pacing before feeding and increased drinking and pecking at non-food objects afterwards. The expression of these activities varies between individuals, it is often stereotyped in form and correlated positively with the level of food restriction imposed (Koštál et al. 1992; Savory and Maros 1993). Based on pharmacological manipulation of different neurochemical receptor systems it was found that expression of the post-feeding oral stereotypies of restricted-fed broiler breeders was more sensitive to treatment with dopamine receptor agonists and antagonists than to manipulation of other systems (Koštál and Savory 1994; Koštál and Savory 1996; Savory and Koštál 1994). Hypothesis on dopaminergic nature of oral stereotyped behaviour is further supported by increased dopamine levels in basal telencephalon (Koštál et al. 1999) and up-regulation of $\mathrm{D}_{1}$ and down-regulation of $\mathrm{D}_{2}$ receptors in several forebrain regions (Koštál et al. 2001) found in restricted-fed broiler breeder hens compared to ad libitum fed ones.

Chronic food restriction in broiler breeders causes various hormonal changes, including an increase in plasma concentrations of growth hormone $(\mathrm{GH})$ and thyroxine $\left(\mathrm{T}_{4}\right)$ and decrease in plasma concentrations of insulin-like growth factor I (IGF-I) and triiodothyronine $\left(\mathrm{T}_{3}\right)$ (Bruggeman et al. 1997; Van der Geyten et al. 1999; Buyse et al. 2000). Changes in GH and IGF-I (Hocking et al. 1994) as well as in thyroid hormones secretion (Bruggeman et al. 1997) have been suggested as possible mechanisms causing differences in egg production between ad libitum and food restricted broiler breeders.

Corticosterone is the principal glucocorticoid released by the avian adrenal gland (Whittow 2000) and elevated plasma corticosterone is an accepted indicator of stress condition in birds (Siegel 1995). Chronic food restriction in broiler breeders has been shown to increase corticosterone levels (Savory et al. 1996; Savory and Mann 1997; Hocking et al. 1998). However, care must be taken in interpretation of results, since a rise in concentration is a normal response to fasting and is thus an indicator of physiological state which may or may not be indicative of stress.

Qualitative restriction of nutrient intake by appropriate dietary dilution or appetite suppression, with free access to food, has been suggested as a less stressful alternative to quantitative restriction for limiting growth rate in parent stock of broilers (Savory et al. 1993, 1996). However, suppression of abnormal oral behaviours did not correspond with reduction in blood indices of stress, including corticosterone levels (S a v ory et al. 1996).

The aim of this study was to examine the effects of qualitative and quantitative food restriction on behavioural, endocrine and metabolic parameters of growing broiler breeder hens and to contribute to the assessment of their welfare status.

Materials and Methods

Twenty four broiler breeder hens Ross 208 (Xaveross, Prague, Czech Republic) were used in the experiment. For the first 2 weeks of life they were kept in cages $60 \times 40 \times 35 \mathrm{~cm}(\mathrm{w} \times \mathrm{d} \times \mathrm{h})(12$ individuals per cage $)$ with food and water provided ad libitum. At the age of 2 weeks hens were randomly divided into 4 feeding treatments $(6$ indivuduals per treatment, 3 individuals per cage). Starting from the beginning of week 7 hens were moved into individual cages measuring $40 \times 44 \times 41 \mathrm{~cm}$. Cages were arranged in two batteries, each consisting of 7 cages in 3 tiers. Four hens (one per each treatment) were placed into each tier. Empty cages between cages occupied by hens prevented them from reaching feeders of the neighbouring hens. Moreover, cardboard placed inside the empty cages prevented them from seeing each other. Hens belonging to distinct feeding treatments were arranged in batteries in a balanced way. The photoperiod was $23 \mathrm{~h}$ light and $1 \mathrm{~h}$ dark (23L : 1D) during the first 2 days and decreased progressively to $12 \mathrm{~L}: 12 \mathrm{D}(06.00-18.00 \mathrm{~h})$ at day 6 . The temperature was gradually reduced from $30{ }^{\circ} \mathrm{C}$ on the first day to $21^{\circ} \mathrm{C}$ from 24 days of age onwards.

At 7 weeks of age a starter diet ( $200 \mathrm{~g}$ crude protein per $\mathrm{kg}, 11.5 \mathrm{MJ} \mathrm{kg}^{-1}$ metabolisable energy) was changed to a grower diet (170 g crude protein per kg, $12.0 \mathrm{MJ} \mathrm{kg}^{-1}$ metabolisable energy). Both diets were in mash form.

Hens belonging to the first feeding treatment were provided with food ad libitum (AL). Hens in the second feeding treatment, qualitative restriction (QR), had free access to food diluted with $30 \%$ of hardwood sawdust. Hens 
belonging to the last two feeding treatments were subjected to quantitative food restriction and received their weighed daily ration once a day at $9.00 \mathrm{~h}$. Hens form the third feeding treatment received twice the amount of daily food ration recommended by the Ross 208 Parent Stock Management Manual (2R) and hens from the fourth treatment received the recommended restricted ration $(\mathrm{R})$. Drinking water was freely available to all treatments. The food consumption (up to 7 weeks of age mean per cage and then individual) was measured daily at $9.00 \mathrm{~h}$, together with refilling of food dispensers. Body weight was recorded once a week.

At the age of 11,12 and 13 weeks hens were observed once each week during the three 30 min periods commencing $09.30,13.30$ and 17.30 (to take account of diurnal variation in behaviour). Observations were made by two observers. Each of them observed one battery, i.e. 12 hens. Before the start of observation the observers sat quietly for $5 \mathrm{~min}$ in front of the cages, to get the hens accustomed to their presence. To be able to see hens in the highest tier, the observers sat on a small ladder. Each hen's behaviour was recorded every minute from a single 'on the dot' (Slater 1978) observation. Following activities were recorded: pecking at feeder (full or empty), drinker directed activity, object pecking, sitting (only or with panting), standing (only or with panting), pacing, preening while sitting and preening while standing. The proportions of time spent in the various activities were calculated from the recordings.

At the end of the experiment at 13 weeks of age, blood samples from the brachial vein were collected using a heparinised syringe. The blood was transferred into chilled tubes and then centrifuged. The plasma was removed and stored at $-20^{\circ} \mathrm{C}$ until assayed for hormone and metabolic parameters. Corticosterone concentration was determined by radioimmunoassay using the method of Ježová et al. (1994). Thyroid hormones were determined by direct radioimmunoassay without extraction. $\mathrm{T}_{3}$ was assayed using the method of Földes et al. (1978) and $\mathrm{T}_{4}$ using commercially available kit (Immunotech, Prague, Czech Republic). Metabolic parameters in plasma (total protein, uric acid, creatinine, glucose, triacylglycerols, cholesterol) were determined with the commercially available kits (Roche, Switzerland) using the Hitachi 911 analyser (Roche, Switzerland).

The effects of age and feeding treatment on body weight were estimated by two-way ANOVA, the effects of testing week, time of day and feeding treatment on the proportion of time spent by distinct behaviours were estimated by three-way ANOVA and the effect of feeding treatment on hormone concentrations and metabolic parameters were estimated by one-way ANOVA. Differences between means were determined by the least significant difference (LSD) procedure.

\section{Results}

Body weight of $\mathrm{R}$ hens corresponded to the values described in the Ross 208 Parent Stock Management Manual. Body weight of QR hens was between that of $2 \mathrm{R}$ and $\mathrm{R}$ hens during the most of the studied period, however, at 12 weeks of age it was comparable to that of $2 \mathrm{R}$ hens and in 13 weeks of age it was higher than that of the $2 R$ hens. At 13 week of age the mean body weight \pm SEM in distinct treatments was as follows: AL $3561 \pm 130 \mathrm{~g}$, QR 2710 $\pm 199 \mathrm{~g}, 2 \mathrm{R} 2546 \pm 47 \mathrm{~g}$ and $\mathrm{R} 1558 \pm 24 \mathrm{~g}$ (Fig. 1A). The results of the ANOVA showed significant effect of age $(p<0.001)$, feeding treatment $(p<0.001)$ and their interaction $(p<$ $0.001)$ on body weight.
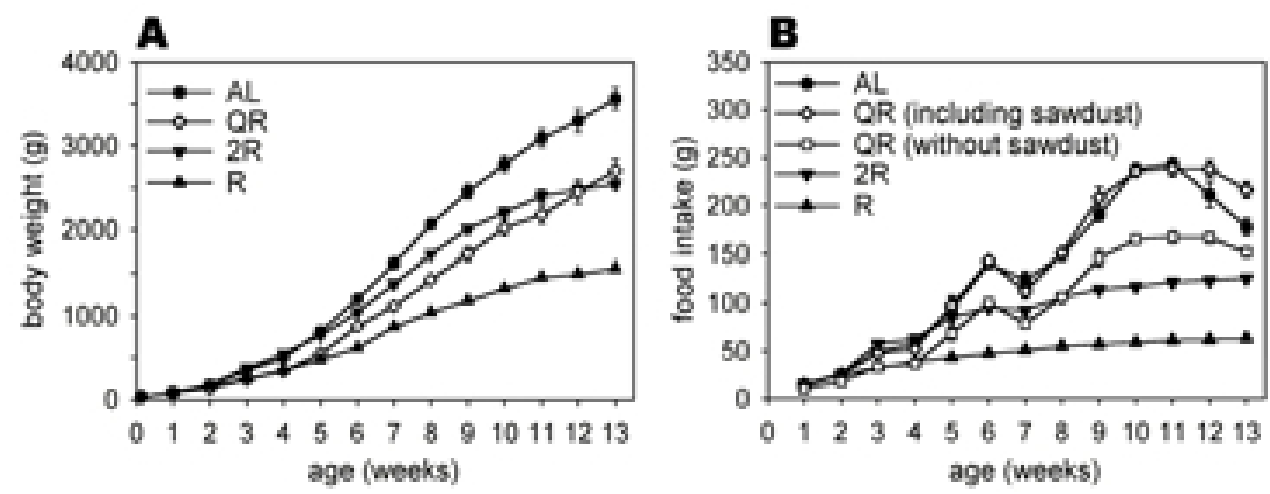

Fig. 1. Mean body weight (A) and food intake (B) at different ages of hens fed on the restricted ration recommended by the breeding company $(\mathrm{R})$, twice that amount $(2 \mathrm{R})$, fed by the diet diluted with $30 \%$ sawdust (QR) and ad libitum (AL). $\mathrm{n}=6$ per treatment 
Table 1

Significance ( $p$-levels) of the effects of testing week $(\mathrm{W})$, time of day $(\mathrm{T})$, feeding treatment $(\mathrm{F})$ and their interactions on proportion of time spent by distinct behaviours. Results from three-way ANOVA.

\begin{tabular}{|l|c|c|c|c|c|c|c|}
\hline & \multicolumn{3}{|c|}{ Main effects } & \multicolumn{4}{c|}{ Interactions } \\
\hline & $\mathrm{W}^{1}$ & $\mathrm{~T}^{2}$ & $\mathrm{~F}^{3}$ & $\mathrm{~W} \times \mathrm{T}$ & $\mathrm{W} \times \mathrm{F}$ & $\mathrm{T} \times \mathrm{F}$ & $\mathrm{W} \times \mathrm{T} \times \mathrm{F}$ \\
\hline Pecking at feeder & n.s. & 0.001 & 0.001 & n.s. & n.s. & 0.001 & n.s. \\
\hline Drinker directed activity & n.s. & n.s. & 0.001 & n.s. & n.s. & 0.05 & n.s. \\
\hline Object pecking & n.s. & n.s. & n.s. & n.s. & n.s. & n.s. & n.s. \\
\hline Sitting & n.s. & 0.001 & 0.001 & n.s. & n.s. & n.s. & n.s. \\
\hline Standing & n.s. & 0.001 & 0.001 & n.s. & n.s. & 0.001 & n.s. \\
\hline Pacing & 0.05 & 0.05 & 0.01 & n.s. & n.s. & n.s. & n.s. \\
\hline Preening & n.s. & 0.001 & 0.01 & n.s. & n.s. & 0.05 & n.s. \\
\hline
\end{tabular}

${ }^{1}$ behavioural tests at 11,12 and 13 weeks of age

230 min behavioural tests commencing at $9.30,13.30$ and 17.30

${ }^{3}$ four feeding treatments - AL, QR, 2R and R - see Materials and Methods for details

Figure 1B illustrates food intake in distinct feeding treatments. Starting from 2 and 5 weeks of age $\mathrm{R}$ and $2 \mathrm{R}$ hens, respectively, consumed the whole amount of food provided in the daily meal. Food consumption curve of QR hens (food mash + sawdust) with free access to food followed the food consumption curve of AL hens. Drop in the food intake at the age of seven weeks in AL and QR hens and to a lesser extent in $2 \mathrm{R}$ hens was connected with the change from group to individual housing as well as with the change from starter to grower diet (Fig. 1B).

Statistical analysis of behavioural data (Table 1) proved that there was no significant effect of the testing week on behaviour (except pacing), i.e. behaviour of hens over the three testing weeks was stable and therefore we presented it in Fig. 2 as the means of the observations during consecutive 3 weeks (week 11 to 13). On the other hand, there was highly significant effect of the time of day on behaviours (except drinker directed activity and object pecking) and feeding treatment on behaviours (except object pecking). Out of the interactions the only significant was the effect of an interaction between the time of day and feeding treatment in case of pecking at feeder, drinker directed activity, standing and preening (Table 1), indicating different distribution of behaviours during the day in hens belonging to distinct feeding treatments. There were no intensive changes in behaviour of hens with free access to food (AL and QR) related to the time of day (Fig. 2). In contrast, there was marked diurnal variation in behaviour of quantitatively restricted hens. During the first observation period (09.30-10.00) there were still remains of the food mash in feeders of the $2 \mathrm{R}$ and $\mathrm{R}$ hens. However, during the second and third observation period the feeders were already empty, but pecking at (empty) feeder only gradually decreased. Although there were differences in time course of the proportion of time spent by pecking at feeder (full and empty combined) between QR and R hens (Fig. 2), sum of the occurrence of this behaviour over the whole day in $\mathrm{R}$ hens, as well as in $\mathrm{QR}$ ones, was higher in comparison with both $\mathrm{AL}$ and $2 \mathrm{R}$ hens ( $\mathrm{R}>\mathrm{AL}, p<0.001 ; \mathrm{R}>2 \mathrm{R}, p<0.01$; $\mathrm{QR}>\mathrm{AL}, p<0.001$; $\mathrm{QR}>2 \mathrm{R}, p<0.05)$. The whole day sum of drinker directed activity, i.e. drinking and drinker manipulation, was higher in birds with free access to food in comparison with those provided with one restricted daily meal (AL $>2 \mathrm{R}, p<0.001$; $\mathrm{AL}>\mathrm{R}, p<0.01$; $\mathrm{QR}>2 \mathrm{R}, p<0.001$; $\mathrm{QR}>\mathrm{R}, p<0.001$ ). There was less sitting observed in hens with single restricted daily meal as compared to those with free access to food ( $\mathrm{R}<\mathrm{AL}, p<0.001 ; 2 \mathrm{R}<\mathrm{AL}, p<0.001 ; \mathrm{R}<\mathrm{QR}, p<0.001 ; 2 \mathrm{R}<$ $\mathrm{QR}, p<0.05)$. There was also difference between more and less intensive quantitative food restriction in proportion of time spent sitting $(\mathrm{R}<2 \mathrm{R} ; p<0.05)$. There was more standing (mainly at the end of day) in quantitatively restricted hens than in those with free access to 


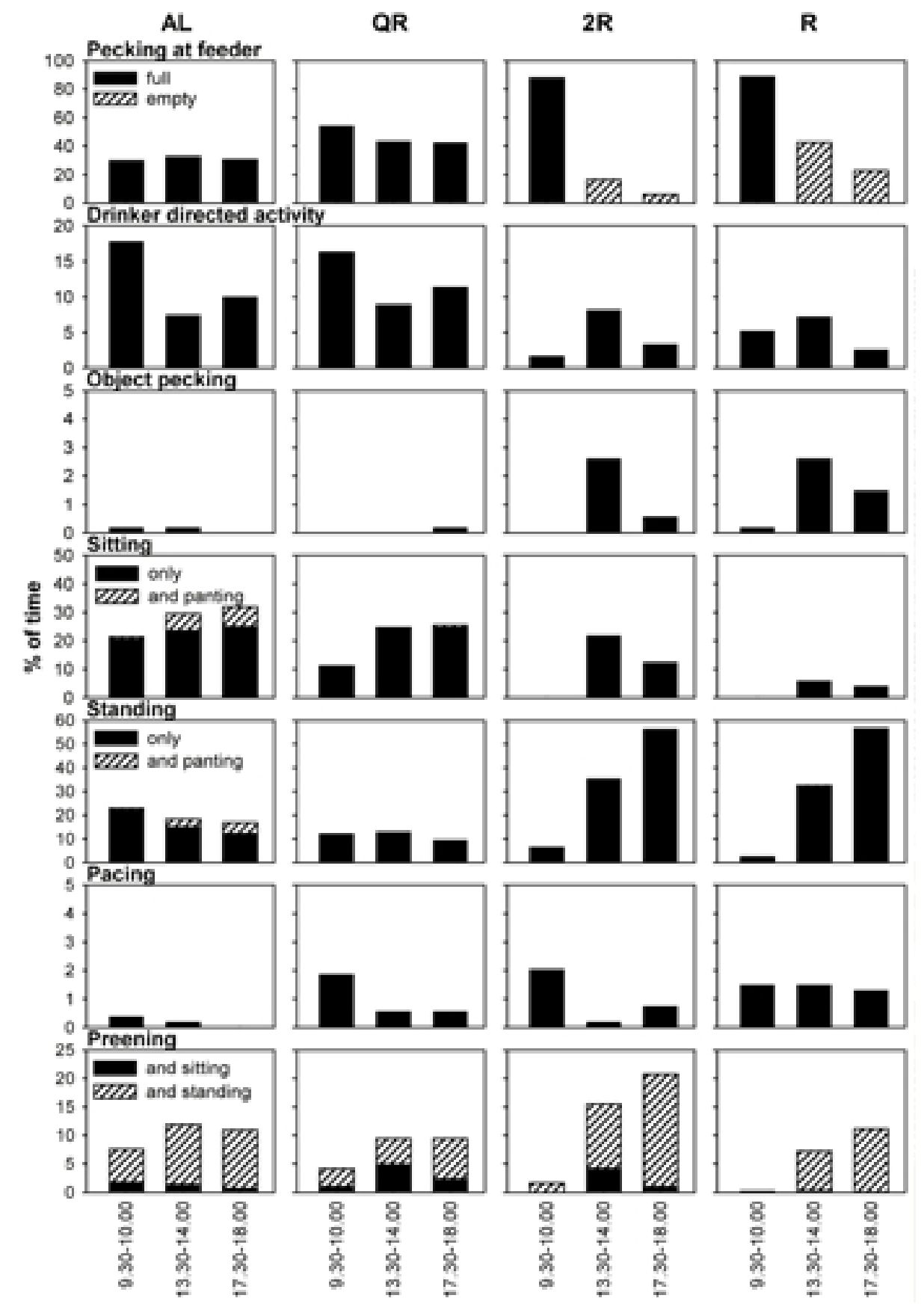

Fig. 2. Mean proportions of time spent in different activities during 30 min commencing at 9.30,13.30 and 17.30. Raws represent distinct behaviours and columns 4 feeding treatments (AL, QR, 2R, R - see Fig. 1 for details). Values represent mean of three observations in 11,12 and 13 weeks of age; $n=6$ per treatment. 
food ( $\mathrm{R}>\mathrm{AL}, p<0.001 ; 2 \mathrm{R}>\mathrm{AL}, p<0.001 ; \mathrm{R}>\mathrm{QR}, p<0.001 ; 2 \mathrm{R}>\mathrm{QR}, p<0.001)$, and in $\mathrm{AL}$ as compared to $\mathrm{QR}$ ones ( $\mathrm{AL}>\mathrm{QR}, p<0.01$ ). Proportion of time spent pacing was in all food restriction treatments higher than in AL hens $(\mathrm{R}>\mathrm{AL}, p<0.001 ; 2 \mathrm{R}>\mathrm{AL}, p<0.05$; $\mathrm{QR}>\mathrm{AL}, p<0.05)$. There was less preening in $\mathrm{R}$ hens in comparison with $\mathrm{AL}$ and $2 \mathrm{R}$ ones $(\mathrm{R}<\mathrm{AL}, p<0.05 ; \mathrm{R}<2 \mathrm{R}, p<0.001)$ and less preening in $\mathrm{QR}$ hens than in $2 \mathrm{R}$ ones $(\mathrm{QR}<$ $2 \mathrm{R}, p<0.01)$.

Plasma concentration of corticosterone (Fig. 3A) in $\mathrm{R}$ hens was significantly higher in comparison with all other treatments $(\mathrm{R}>\mathrm{AL}, p<0.001 ; \mathrm{R}>\mathrm{QR}, p<0.01 ; \mathrm{R}>2 \mathrm{R}, p<$ $0.001)$. While the increase in corticosterone level in $2 \mathrm{R}$ hens as compared to AL ones did not reach the level of statistical significance, the increase in $\mathrm{QR}$ hens in comparison with $\mathrm{AL}$ ones was significant $\left(\mathrm{QR}>\mathrm{AL}, p<0.05\right.$ ). Plasma concentrations of $\mathrm{T}_{3}$ (Fig. 3B) was in all restricted-fed treatments significantly lower in comparison with $\mathrm{AL}$ treatment $(\mathrm{QR}<\mathrm{AL}, p$ $<0.01 ; 2 \mathrm{R}<\mathrm{AL}, p<0.01 ; \mathrm{R}<\mathrm{AL}, p<0.001$ ). In case of plasma concentration of $\mathrm{T}_{4}$ (Fig. $3 \mathrm{C}$ ) there was a trend towards increase in $\mathrm{QR}$ and $2 \mathrm{R}$ hens and significant increase in case of $\mathrm{R}$ hens in comparison with AL control $(\mathrm{R}>\mathrm{AL}, p<0.01)$.
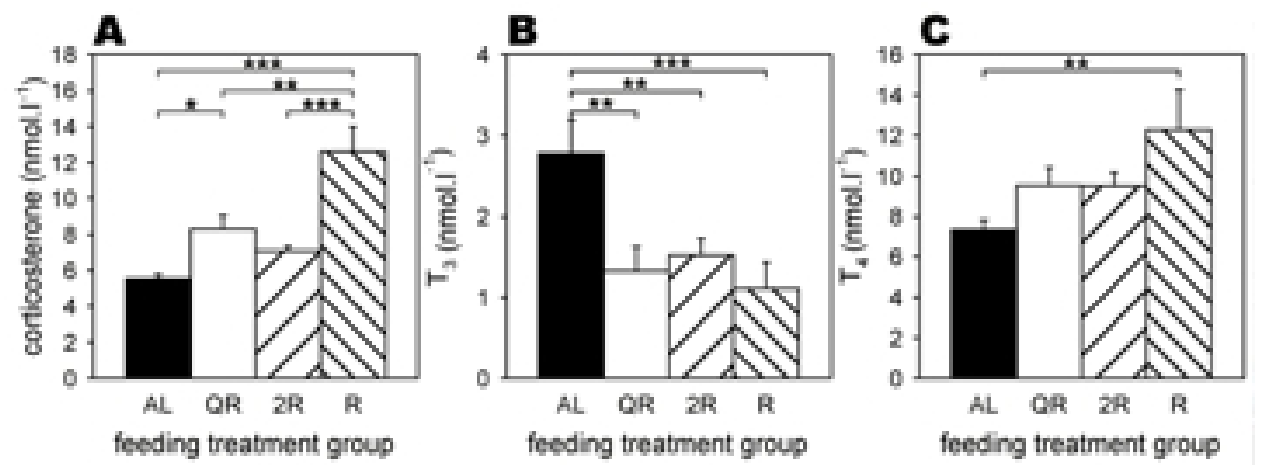

Fig. 3. Plasma concentrations of corticosterone $(A), T_{3}(B)$ and $T_{4}(C)$ in hens belonging to 4 feeding treatments (see Fig. 1). $\mathrm{n}=6$ per group, $* p<0.05, * * p<0.01, * * * p<0.001$

The protein content and glucose concentration in plasma were not changed in hens exposed to qualitative and quantitative food restriction (Fig. 4A, 4D). The uric acid content in plasma of the QR hens was significantly lower in comparison with all other feeding treatments ( $\mathrm{QR}<\mathrm{AL}, p<0.05$; $\mathrm{QR}<2 \mathrm{R}, p<0.05$; $\mathrm{QR}<\mathrm{R}, p<0.05$ ) (Fig. 4B). Food restriction caused elevation of creatinine concentration in $2 \mathrm{R}$ hens in comparison with $\mathrm{AL}$ and $\mathrm{QR}$ hens ( $2 \mathrm{R}>\mathrm{AL}, p<0.05 ; 2 \mathrm{R}>\mathrm{QR}, p<0.01)$ (Fig. 4C). The triacylglycerols levels decreased significantly in $\mathrm{QR}$ hens in comparison with $\mathrm{AL}(\mathrm{QR}<\mathrm{AL}, p<0.05)$, in $\mathrm{R}$ hens compared to all other treatments ( $\mathrm{R}<\mathrm{AL}, p<0.001 ; \mathrm{R}<\mathrm{QR}, p<0.05 ; \mathrm{R}<2 \mathrm{R}, p<0.01$ ) and there was a trend towards decrease in $2 \mathrm{R}$ hens as compared to AL ones (Fig. 4E). On the other side cholesterol levels (Fig. 4F) in plasma of hens from all restricted treatments were significantly increased in comparison with the AL hens $(\mathrm{QR}>\mathrm{AL}, p<0.05 ; 2 \mathrm{R}>\mathrm{AL}, p<$ $0.05 ; \mathrm{R}>\mathrm{AL}, p<0.01)$.

\section{Discussion}

As a result of chronic quantitative and qualitative food restriction at 13 weeks of age the body weights of $\mathrm{R}, 2 \mathrm{R}$ and $\mathrm{QR}$ hens were $0.4,0.7$ and 0.8 fold of AL control. These values as well as food consumption correspond with values reported by other authors in AL, $2 \mathrm{R}$ and R broiler breeder chickens (Bruggeman et al. 1998, 1999; S a vory et al. 1993, 1996). The 

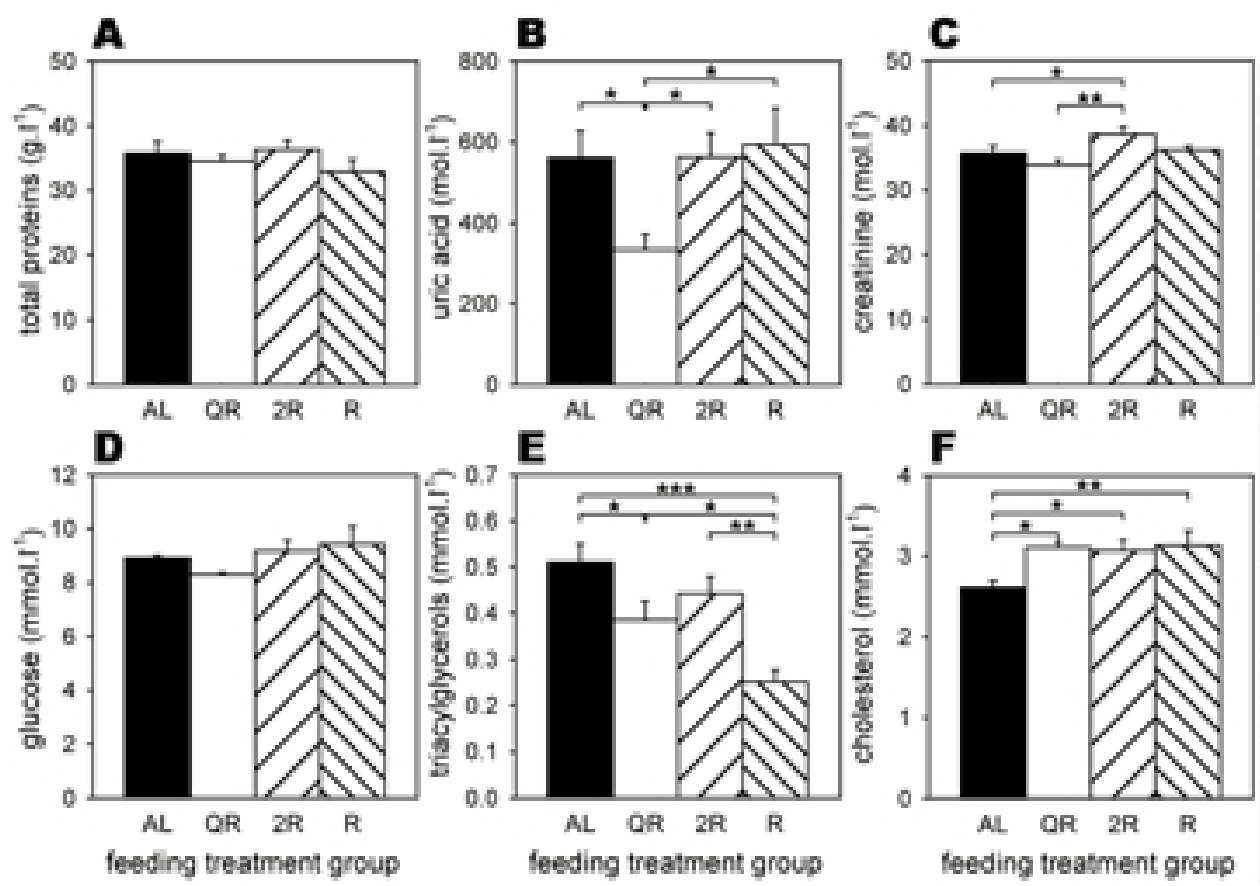

Fig. 4. Total proteins in plasma (A) and plasma concentrations of uric acid (B), creatinine (C), glucose (D), triacylglycerols $(\mathrm{E})$ and cholesterol $(\mathrm{F})$ in hens belonging to 4 feeding treatments (see Fig. 1$) . \mathrm{n}=6$ per group, $* p$ $<0.05, * * p<0.01, * * * p<0.001$

dilution of diet by addition of $50 \%$ sawdust in the study of Savory et al. (1996) reduced the body weight of chickens to the level lower than in $\mathrm{R}$ hens.

Vilariño et al. (1996) showed that time spent by chickens at the trough is affected by the form of food. Hens fed with the pelleted diets spent considerably shorter time at the trough than hens fed with mash. That explains why restricted-fed $(\mathrm{R})$ broiler breeders Ross consumed their daily ration in less than $15 \mathrm{~min}$, when provided as pellets (S a v ory and Maros 1993; Koštál and Savory 1994), while in present experiment under comparable conditions it took them more than 60 min to consume the same amount of food mash.

Marked diurnal variation in behaviour of hens belonging to both quantitatively restricted treatments ( $R$ and $2 R$ ) in present experiment was characterised by decreasing proportion of time spent pecking at feeder and increasing proportion of time spent standing and preening throughout the day. Similar distribution of behaviours during the day in quantitative restricted broiler breeders were reported earlier (Koštál et al. 1992; Savory and Maros 1993; Savory et al. 1996; Savory and Koštál 1996). Minor differences in frequences of behaviours could be attributed to the differences in age and form of food (pellets vs. mash).

Diurnal distribution of activities of QR hens the age of 11 - 13 weeks had similar development to that of $\mathrm{AL}$ treatment. In $\mathrm{QR}$ hens there was reduced amount of oral stereotypies (pecking at objects resp. empty feeder) as compared to $\mathrm{R}$ and $2 \mathrm{R}$ hens. On the other side QR hens were more active than AL ones and spent more time by food intake and pacing. Mash diet, in particular when it is diluted, makes it difficult for hens to satisfy their nutrient requirements. According to Vilariño et al. (1996) this induces a mild frustration 
state in the hen, expressed by numerous visits to the trough over a longer period of time and higher frequency of trough-oriented pecking behaviour. Peletting of diluted diet seems to limit the excessive trough-oriented behaviour and permit the feeding of such diet with no adverse effects on birds' behaviour (Vilariño et al. 1996).

Chronic food restriction represents for organism permanent stress and, as a result, whole spectrum of metabolic processes including a shift from anabolism to catabolism, from lipogenesis to lipolysis, occurs. Adaptive changes are mediated by many metabolic hormones. Data obtained in chickens show that food restriction modifies the plasma levels of hormones involved in energy metabolism and growth processes, such as $\mathrm{T}_{3}, \mathrm{~T}_{4}, \mathrm{GH}$, IGF-I (Darras et al. 1995; Buy se et al. 2000) and corticosterone ( $S$ avory et al. 1996; Hocking et al. 1998, Carsia and Weber 2000).

In our experiment, the significant increase of corticosterone levels in immature (13 weeks old) broiler breeder hens subjected to intensive (recommended by the breeding company) quantitative food restriction was found. Less severe restriction (2R) did not cause corticosterone elevation in comparison with AL. These results are in agreement with results previously obtained by Savory et al. (1996) and Savory and Mann (1997) using similar experimental design. Qualitative food restriction using diet diluted by $30 \%$ of hardwood sawdust in immature broiler breeder hens in this study did not prove the welfare benefits of this procedure. There is an evidence of stress in QR hens. Although the plasma concentration of corticosterone in QR hens was significantly lower than that in R hens, it was still significantly higher than in AL hens. Sav ory et al. (1996) found in hens fed by diet diluted with $50 \%$ of softwood sawdust plasma corticosterone levels substantially higher than in R hens. Much milder qualitative restriction applied here still caused an elevation of corticosterone in comparison with AL hens, although the body weight of these hens was at 13 week comparable with $2 \mathrm{R}$ hens, in which no significant elevation of plasma corticosterone was detected.

Our results showed different response of $\mathrm{T}_{3}$ and $\mathrm{T}_{4}$ plasma concentrations to food restriction. While $\mathrm{T}_{3}$ decreased in all restricted treatments, $\mathrm{T}_{4}$ increased significantly in $\mathrm{R}$ hens and there was a marked trend towards increase in $\mathrm{QR}$ and $2 \mathrm{R}$ hens, all in comparison with the AL hens. These findings are consistent with data from previous studies (Klandorf and Harvey 1985; Newcombe et al. 1992; Bruggeman et al. 1997; Gonzales et al. 1998; Dewil et al. 1999). The most detailed study in broiler breeder hens by Bruggeman et al. (1997) showed, that during ontogeny $\left(2-24\right.$ weeks) $\mathrm{T}_{3}$ concentration decreased and $\mathrm{T}_{4}$ concentration increased in both restricted and ad libitum fed hens. However, a nutrition effect is more marked than the age effect (Bruggem an et al., 1997). The nutritional stimuli are supposed to influence control of thyroid function (Klandorf and Harvey 1985).

There were no significant differences between feeding treatments in plasma glucose or total protein levels found in present experiment. Dewil et al. (1999) described decrease in plasma glucose induced by the short food restriction (1 day) in chickens. However, glucose returned to normal levels, i.e. similar to those recorded in ad libitum fed hens, after a 7 day restriction. This was interpreted in terms of the effectiveness of the glucose homeostatic mechanisms (Dewil et al. 1999). In agreement with this assumption are findings of Rosebrough et al. (1992, 1999), who did not find altered plasma glucose concentrations in male broiler chickens neither in groups with increasing dietary energy : protein ratio nor after addition of the $1 \mathrm{mg}$ of $\mathrm{T}_{3}$ per $\mathrm{kg}$ of diet.

There is controversy in data concerning relation between dietary protein intake and plasma uric acid levels. Hevia and Clifford (1977) reported a positive linear correlation between plasma uric acid and dietary protein intake. On the other hand R osebrough et al. $(1992,1999)$ found in male broiler chickens that decreasing dietary energy: protein ratio 
increased plasma uric acid concentration and addition of $\mathrm{T}_{3}$ into diet decreased uric acid concentration. In present experiment only in $\mathrm{QR}$ hens concentration of uric acid was significantly lower as compared to all other treatments.

In present experiment plasma concentration of triacylglycerols was decreased in $\mathrm{R}$ and QR 13 weeks old broiler breeder hens compared with AL ones. Hocking et al. (1994) reported lower plasma triacylglycerols in one-year-old genetically fat and lean broiler breeder females subjected to food restriction. Rosebrough et al. $(1992,1999)$ found increasing plasma triacylglycerols with increasing dietary energy : protein ratio as well as with an addition of $\mathrm{T}_{3}$ into the diet in male broiler chickens. An association between $\mathrm{T}_{3}$ and triacylglycerols is in accordance with our finding that both plasma $\mathrm{T}_{3}$ and triacylglycerols concentration decreased in a similar manner with increasing food restriction.

Studies of models of physiological stress in chickens using the treatment with ACTH or corticosterone showed that the metabolic changes associated with stress in chicken are increased plasma glucose, total proteins, triacylglyceroles and cholesterol (Davis on et al. 1983; Latour et al. 1996; Puvadolpirod and Thaxton 2000 ab). Response in these metabolic parameters to chronic food restriction differ in several respects. However, increased plasma cholesterol characterise both models.

In summary, there were the signs of reduced welfare detected in hens fed according to the restriction programme recommended by the breeding company. Although the behaviour of qualitative restricted hens reminds more the behaviour of ad libitum fed hens than that of the quantitative restricted ones, it was not associated with reduction in blood indices of stress and so cannot be taken as indicator of improved welfare.

\section{Vplyv reštrikcie krmiva na správanie, endokrinné a metabolické ukazovatele rodičov broilerov}

Sledovali sme vplyv reštrikcie krmiva na správanie, endokrinné a metabolické parametre u 13 týždňových sliepočiek materskej línie kúr mäsového typu (brojlerov). Sliepočky kŕmené ad libitum sme porovnávali s jednou kvalitatívne reštringovanou skupinou (krmivo zriedené $30 \%$ pilín z tvrdého dreva) a s dvoma kvantitatívne reštringovanými skupinami (denná dávka doporučená šlachtitelskou firmou a dvojnásobok tohoto množstva). V správaní kvantitatívne reštringovaných sliepočiek ktoré dostávali jednu dennú kŕmnu dávku boli výrazné diurnálne zmeny, zatial čo prvky správania u sliepočiek s volným prístupom ku krmivu (ad libitum kŕmené a kvalitatívne reštringované) boli rovnomernejšie distribuované počas dňa. Skupina s intenzívnou kvantitatívnou reštrikciou krmiva mala zvýšenú hladinu plazmatického kortikosterónu. Hoci zvýšenie koncentrácie kortikosterónu u skupiny s kvalitatívnou reštrikciou bolo nižšie než u skupiny s kvantitatívnou reštrikciou, bolo v porovnaní s ad libitum kontrolou signifikantné, čo naznačuje, že aj mierna kvalitatívna reštrikcia krmiva je stresujúca. V porovnaní s ad libitum kŕmenými sliepočkami bola u všetkých typov reštrikcie krmiva znížená hladina plazmatického $\mathrm{T}_{3}$, zatial čo plazmatický $\mathrm{T}_{4}$ bol vplyvom intenzívnej kvantitatívnej reštrikcie zvýšený. Reštrikcia krmiva neovplyvnila koncentráciu plazmatickej glukózy ani celkových bielkovín, ale hladina triacylglycerolov bola znížená a cholesterolu zvýšená ako dôsledok reštrikcie. Koncentrácia kreatinínu bola zvýšená u sliepočiek s miernejšou formou kvantitatívnej reštrikcie a koncentrácia kyseliny močovej znížená u kvalitatívne reštringovaných sliepočiek $\mathrm{v}$ porovnaní $\mathrm{s}$ ostatnými skupinami. Tieto výsledky ukazujú, že hoci správanie kvalitatívne reštrikčne kŕmených pripomína viac správanie ad libitum kŕmených sliepočiek, ich fyziologický stav je podobný viac kvantitatívne reštringovaným sliepočkám. 


\section{Acknowledgements}

This work was supported by the grant $\mathrm{N}^{\circ} 2 / 6021 / 21$ of the Slovak Grant Agency for Science (VEGA). We wish to thank Xaveross Prague for donating chicks, Daniela Ježová, the Institute of Experimental Endocrinology, Slovak Academy of Sciences, Bratislava, for the corticosterone assay, Pavel Blažíček, the Hospital of the Ministry of Defence, Bratislava, for the metabolic parameters assay, and Katka Šmidáková, for the excellent technical assistance.

\section{References}

BRUGGEMAN, V., D'HONDT, E., BERGHMAN, L., ONAGBESAN, O., VANMONTFORT, D., VANDESANDE, F., DECUYPERE, E. 1998: The effect of food intake from 2 to 24 weeks of age on LHRH-I content in the median eminence and gonadotrophin levels in pituitary and plasma in female broiler breeder chickens. Gen. Comp. Endocrinol. 112: 200-209

BRUGGEMAN, V., ONAGBESAN, O., D'HONDT, E., BUYS, N., SAFI, M., VANMONTFORT, D., BERGHMAN, L., VANDESANDE, F., DECUYPERE, E. 1999: Effect of timing and duration of feed restriction during rearing on reproductive characteristics in broiler breeder females. Poult. Sci. 78: 1424-1434

BRUGGEMAN, V., VANMONTFORT, D., RENAVILLE, R., PORTETELLE, D., DECUYPERE, E. 1997: The effect of food intake from two weeks of age to sexual maturity on plasma growth hormone, insulin-like growth factor-I, insulin-like growth factor-binding proteins, and thyroid hormones in female broiler breeder chickens. Gen. Comp. Endocrinol. 107: 212-220

BUYSE, J., DECUYPERE, E., DARRAS, V.M., VLEURICK, L.M., KÜHN, E.R., VELDHUIS, J.D. 2000: Food deprivation and feeding of broiler chickens is associated with rapid and interdependent changes in the somatotrophic and thyrotrophic axes. Br. Poult. Sci. 41: 107-116

CARSIA, R.V., WEBER, H. 2000: Dietary protein restriction stress in the domestic chicken (Gallus gallus domesticus) induces remodeling of adrenal steroidogenic tissue that supports hyperfunction. Gen. Comp. Endocrinol. 120: $99-107$

DARRAS, V.M., COKELAERE, M., DEWIL, E., ARNOUTS, S., DECUYPERE, E., KUHN, E.R. 1995: Partial food restriction increases hepatic inner ring deiodinating activity in the chicken and the rat. Gen. Comp. Endocrinol. 100: $334-338$

DAVISON, T.F., REA J., ROWELL J.G. 1983: Effects of dietary corticosterone on the growth and metabolism of immature Gallus domesticus. Gen. Comp. Endocrinol. 50: 463-468

DEWIL, E., DARRAS V.M., SPENCER G.S.G., LAUTERIO T.J., DECUYPERE, E. 1999: The regulation of GHdependent hormones and enzymes after feed restriction in dwarf and control chickens. Life Sci. 64: 1359-1371

FÖLDES, O., HRČKA, R., VELINSKY, J., KOKEŠOVÁ, H., LANGER, P., LIŠTIAKOVÁ, M. 1978: The sensitive radioimmunoassay of L-thyroxine in serum. Biochem. Clin. Bohemoslov. 7: 145-151

GONZALES, E., BUYSE, J., LODDI, M.M., TAKITA, T.S., BUYS, N., DECUYPERE E. 1998: Performance, incidence of metabolic disturbances and endocrine variables and food-restricted male broiler chickens. Br. Poult. Sci. 39: 671-678

HAN, P.F.S., SMYTH, J.R. 1972: The influence of restricted feed intake on the response of chickens to Marek's disease. Poult. Sci. 51: 986-990

HEVIA, P., CLIFFORD, A.J. 1977: Protein intake, uric acid metabolism and protein efficiency ration in growing chicks. J. Nutr. 107: 959-964

HOCKING, P.M. 1999: Welfare of broiler breeders. Proceedings of the WPSA Spring Meeting, Scarborough, UK, 24-25 March 1999, pp. 18-23

HOCKING, P.M., BERNARD, R., WILKIE, R.S., GODDARD, C. 1994: Plasma growth hormone and insulinelike growth factor-I (IGF-I) concentrations at the onset of lay in ad libitum and restricted broiler breeder fowl. Br. Poult. Sci. 35: 299-308

HOCKING, P.M., DUFF, S.R.I. 1989: Musculo-skeletal lesions in adult male broiler breeder fowls and their relationships with body weight and fertility at 60 weeks of age. Br. Poult. Sci. 30: 777-784

HOCKING, P.M., GILBERT, A.B., WALKER, M., WADDINGTON, D. 1987: Ovarian follicular structure of white leghorns fed ad libitum and dwarf and normal broiler breeders fed ad libitum or restricted until point of lay. Br. Poult. Sci. 28: 493-506

HOCKING, P.M., MAXWELL, M.H., MITCHELL, M.A. 1996: Relationships between the degree of food restriction and welfare indices in broiler breeder females. Br. Poult. Sci. 37: 263-278

HOCKING, P.M., MAXWELL, M.H., MITCHELL, M.A., ROBERTSON, G.W. 1998: Welfare and productivity of restricted broiler breeder females fed ad libitum or restricted after the peak of egg production. Br. Poult. Sci. 39: $\mathrm{S} 16-\mathrm{S} 17$

JEŽOVÁ, D., GUILlaume, V., JURÁNKOVÁ, E., CARAYON, P., OLIVER, C. 1994: Studies of the physiological role of ANF in ACTH regulation. Endocr. Regul. 28: 163-169

KATANBAF, M.N., E.A. DUNNINGTON, AND P.B. SIEGEL, 1989. Restricted feeding in early and latefeathering chickens. 1. Growth and physiological responses. Poult. Sci. 68: $344-351$

KLANDORF, H., HARVEY, S. 1985: Food intake regulation of circulating thyroid hormones in domestic fowl. Gen. Comp. Endocrinol. 60: 162-170 
KOŠŤÁL, L, KUBÍKOVÁ, L, VYBOH, P., BILČÍK, B., SAVORY, C.J. 2001: The effects of food restriction on behaviour and dopamine $\mathrm{D}_{1}$ and $\mathrm{D}_{2}$ receptor densities in domestic chicks. Advances in Ethology 36: 195.

KOŠŤ́́L, L, VYBOH, P., SAVORY, C.J., JURÁNI, M., KUBÍKOVÁ, L, BLAŽÍČEK, P. 1999: Influence of food restriction on dopamine receptor densities, catecholamine concentrations and dopamine turnover in chicken brain. Neuroscience 94: 323-328

KOŠŤ́L, L., SAVORY, C.J., HUGHES, B.O. 1992: Diurnal and individual variation in behaviour of restrictedfed broiler breeders. Appl. Anim. Behav. Sci. 32: 361-374

KOŠŤÁL, L., SAVORY, C.J. 1994: Influence of pharmacological manipulation of dopamine and opioid receptor subtypes on stereotyped behaviour of restricted-fed fowls. Pharmacol. Biochem. Behav. 48: 241-252

KOŠŤÁL, L., SAVORY, C.J. 1996: Behavioural responses of restricted-fed fowls to pharmacological manipulation of 5-HT and GABA receptor subtypes. Pharmacol. Biochem. Behav. 53: 995-1004

LATOUR, M.A., LAICHE, S.A., THOMPSON, J.R., POND, A.L., PEEBLES, E.D. 1996: Continuous infusion of adrenocorticotropin elevates circulating lipoprotein cholesterol and corticosterone concentrations in chickens. Poult. Sci. 75: 1428-1432

NESTOR, K.E., BACON, W.L., RENNER, P.A. 1980: The influence of genetic changes in total egg production, clutch length, broodiness, and body weight on ovarian follicular development in turkeys. Poult. Sci. 59: 16941699

NEWCOMBE, M., CARTWRIGHT, A.L., HARTER-DENNIS, J.M., MCMURTRY, J.P. 1992: The effect of increasing photoperiod and food restriction in sexed, broiler-type birds. II. Plasma thyroxine, triiodothyronine, insuline-like growth factor-I and insulin. Br. Poult. Sci. 33: 427-435

O'SULLIVAN, N.P., DUNNINGTON, E.A., SMITH, E.J., GROSS, W.B., SIEGEL, P.B. 1991: Performance of early and late feathering broiler breeder females with different feeding regimens. Br. Poult. Sci. 32: 981-995

PUVADOLPIROD, S., THAXTON, J.P. 2000a: Model of physiological stress in chickens 1. Response parameters. Poult. Sci. 79: 363-369

PUVADOLPIROD, S., THAXTON, J.P. 2000b: Model of physiological stress in chickens 2. Dosimetry of adrenocorticotropin. Poult. Sci. 79: 370-376

Report of the Scientific Committee on Animal Health and Animal Welfare: The Welfare of Chickens Kept for Meat Production (Broilers), March 2000, European Commission, Health and Consumer Protection DirectorateGeneral

ROBINSON, F.E., WILSON, J.L., YU, M.W., FASENKO, G.M., HARDIN, R.T. 1993: The relationship between body weight and reproductive efficiency in meat-type chickens. Poult. Sci. 72: 912-922

ROSEBROUGH, R.W., MCMURTRY, J.P., VASILATOS-YOUNKEN, R. 1992: In vitro lipid metabolism, growth and metabolic hormone concentrations in hyperthyroid chickens. Br. J. Nutr. 68: 667-676

ROSEBROUGH, R.W., MCMURTRY, J.P., VASILATOS-YOUNKEN, R. 1999: Dietary protein effects on the broiler's adaptation to triiodothyronine. Growth Dev. Aging 63: 85-98

SAVORY, C.J., HOCKING, P.M., MANN, J.S., MAXWELL, M.H. 1996: Is broiler breeder welfare improved by using qualitative rather than quantitative food restriction to limit growth rate? Anim. Welfare 5: 105-127

SAVORY, C.J., KOŠŤÁL, L. 1994: The role of adrenoreceptors in control of stereotyped oral behaviour in restricted-fed fowls. Pharmacol. Biochem. Behav. 49: 295-302

SAVORY, C.J., KOŠŤ́́L, L. 1996: Temporal patterning of oral stereotypies in restricted-fed fowls: 1. investigations with a single daily meal. Int. J. Comp. Psychol. 9: 117-139

SAVORY, C.J., MANN, J.S. 1997: Is there a role for corticosterone in expression of abnormal behaviour in restricted-fed fowls? Physiol. Behav. 62: 7-13

SAVORY, C.J., MAROS, K. 1993: Influence of degree of food restriction, age and time of day on behaviour of broiler breeder chickens. Behav. Proc. 29: 179-190

SAVORY, C.J., MAROS, K., RUTTER, S.M. 1993: Assessment of hunger in growing broiler breeders in relation to a commercial restricted feeding programme. Anim. Welfare 2: 131-152

SIEGEL, H.S. 1995: Gordon memorial lecture. Stress, strains and resistance. Br. Poult. Sci. 36: 3-22

SLATER, P.J.B. 1978: Data collection. In: COLGAN, P.W. (ed.): Quantitative Ethology. Wiley, New York, pp. 7-24

VAN DER GEYTEN, S., VAN ROMPAEY, E., SANDERS, J.P., VISSER, T.J., KÜHN, E.R., DARRAS, V.M. 1999: Regulation of thyroid hormone metabolism during fasting and refeeding in chicken. Gen. Comp. Endocrinol. 116: 272-280

VILARIĄO, M., PICARD, M.L., MELCION, J.P., FAURE, J.M. 1996: Behavioural adaptation of laying hens to dilution of diets under mash and pellet form. Br. Poult. Sci. 37: 895-907

WHITTOW, G.C. (ed.) 2000: Sturkie's Avian Physiology. $5^{\text {th }}$ edition, Academic Press, San Diego, 685 p. 